\title{
Moodle-based Distance Language Learning Strategies: An Evaluation of Technology in Language Classroom
}

\author{
Majid Khabbaz \\ Faculty of Border Sciences, Amin Police University, Tehran, Iran \\ E-mail:khabbaz_m@yahoo.com \\ Rasool Najjar (Corresponding author) \\ Faculty of Border Sciences, Amin Police University, Tehran, Iran \\ E-mail: Najjar.Rassol@yahoo.com
}

Received: 16-12- 2014

Published: 01-07-2015
Accepted: 18-02- 2015

doi:10.7575/aiac.ijalel.v.4n.4p.205
Advance Access Published: February 2015

URL: http://dx.doi.org/10.7575/aiac.ijalel.v.4n.4p.205

\begin{abstract}
English language teaching curriculum developers now turn to the heavy use of technology in classrooms. Computer technology, specifically, has brought about many changes in the strategies of language leaning. One of the new computer programs which has recently attracted the attention of language teachers is called Moodle. It is an opensource Course Management System (CMS) which delivers online courses as well as supplement traditional face-to-face language courses. Since there is little information about the feasibility of such a program, this study is an effort to examine it through its adaptability to Language Learning Strategies (LLSs). The data is gathered from 60 Moodle-based EAP users as a purposeful sample of the EAP population through a questionnaire. The participants were also observed and interviewed (6 participants). It was found out that there were no relationships between LLSs and language achievement at Moodle-based distance language learning contexts. The findings imply that learning language through Moodle-based teaching materials impede the process of being autonomous language learners, which is a prerequisite for language learning at distance contexts.
\end{abstract}

Keywords: distance learning, language learning strategies, learner autonomy, Computer-Assisted Language Learning, English for Academic Purposes (EAP)

\section{Introduction}

Technology-based learning is introduced as a kind of learning "delivered via any technology" (Anohina, 2005). Technology, therefore, is considered as a resource from which any tool can be selected for learning processes. Focused on this conceptual framework, educators select different, sometimes untried, technologies in order to facilitate the process of teaching and learning. The widespread use of technologies has even changed the understanding of what it means to teach and learn a language, and teaching roles, in response to these changes, are being altered and transformed (White, 2007). It has, therefore, brought different expressions into Second/Foreign Language Learning (ESL/EFL), such as distance language learning, online language learning, distributed language learning, virtual language learning, computer-assisted language learning, and web-based language learning (Anohina, 2005).

Since the availability and simple structure of technologies were important, powerful packages known as Learning Management Systems (LMSs) were developed to enhance learning in a variety of environments (Melton, 2006). Due to high fees, however, many LMSs, such as WebCT and Blackboard, require a commercial support that language teachers cannot afford. To solve the problem, Moodle (Modular object-oriented dynamic/developmental learning environment) came out as an open source LMS. Due to both the ubiquity of the internet and increased availability of network bandwidth, this powerful package attracted the interest of many educators all over the world (Cole, 2005). Teachers who use Moodle have access to an array of powerful tools, including assignments, forums, journals, quizzes, surveys, chat rooms, and workshops (Cole, 2005). In spite of its widespread use, there are few reliability, quality, and feasibility signs for Moodle program when used for language teaching/learning. This study, therefore, is to answer the problem of whether or not Moodle-based language teaching is worth increasing language learning.

\subsection{Review of Literature}

Many studies have proven the positive effect of distance teaching on language learning (Gascoigne, 2008; Holmberg, Shelley, \& White, 2005; Hurd, 2008; Murphy, 2008; White, 2003a; White, 2007). It is the autonomy and independency of language learners which help them compensate for lack of face to face interaction existing in conventional language teaching environments (Sarani, Ghonsooly, \& Najjar, 2013). White $(1995,2003 b)$ introduced strategy use as a factor indicating the level of autonomy at distance contexts. Accordingly, distance language learners are more autonomous and self-regulated (Hurd, 2008; Hurd, Beaven, \& Ortega, 2001). Oxford (2008) also established a direct relationship 
between independent learning (distance learning), learner autonomy, and learning strategies. According to Oxford, "The uses of learning strategies can both reflect and further promote learner autonomy" (p.41).

Along with this theoretical framework, many studies resulted in using metacognitive strategies more than the other direct and indirect strategies at distance contexts. It implies that distance language learners use self-regulated strategies in order to enhance their autonomy and self-pacing learning (Ping, 2004; White, 1995, 2003a; Zahedi \& Dorrimanesh, 2008). Zahedi and Dorrimanesh (2008), for example, focused on metacognitive Language Learning Strategies (LLSs) at distance contexts. They surprisingly found a relationship between distance learning strategies and English for Academic Purposes (EAP). It seems that EAP contexts increase the use of language learning strategies (Najjar, 2011).

Although distance language learners use metacognitive language strategies, they adhere to affective strategies at the low level (Hurd, 2008; Najjar, 2011). While this finding needs to be supported by more evidence form similar studies, it shows that distance learners rely mostly on their cognition rather than affection.

There have been some comparative studies which compare LLSs at distance contexts with conventional contexts. For example, Hanson and Wenno (2005) compared how differently compensatory strategies were used in both conventional and distance language learning strategies. Their study showed that the natural deficiencies of a distance course (such as lack of communication and print-based materials) have to be compensated for by effective sources. In addition to compensation strategies, Chan and Han (2005) examined writing strategies. They found that online students are more aware of strategy use in the way that there is a positive relationship between strategy use and writing awareness at distance contexts.

Learners' variables such as age and sex of distance language learners have also been explored in terms of the level of strategy use. In other words, some studies tried to examine whether male or female use LLSs differently (Bagheri, Yamini, and Riazi, 2009). According to these studies, it is almost possible to say that there are significant differences between males/females motivation strategies in the way that females used more motivation and learning strategies.

In general, the implication of the review of related literature is that distance language learners use more metacognitive LLSs. There is also little evidence to support this finding for EAP distance learners (see, for example, Sarani, Ghonsooly, \& Najjar, 2012). However, few studies exist to support the pedagogical value of LLSs at EAP distance learning contexts. It follows that the existing literature is not so reliable to imply that EAP learners are also more autonomous and that the use of LLSs contributes toward language learning. Moreover, little attention has been paid to the Moodle-based distance language learning contexts. Therefore, this paper is to explore whether DLLSs used by EAP learners at a Moodle-based distance contexts result in language success. It also aims to fill in the gap of lacking enough information on the realm of using metacognitive strategies by distance language learners, which can be an indicator of being more autonomous at distance contexts.

\subsection{Research Questions}

A useful tool for evaluating language programs at distance contexts and technology-based contexts is the qualification of these programs in promoting learners autonomy (Hurd, 2008; Oxford, 2008; White, 1995, 2003b). White (2003a) believes that distance language learners are more self-ruled, self-regulated, and autonomous than their counterparts at face-to-face language learning contexts. To measure autonomy, Oxford (2008) proposed measuring learning strategies and added that "the use of learning strategies can both reflect and further promote learner autonomy" (p. 41). Whether Moodle, therefore, is an effective program in terms of its usability in language learning and teaching can be evaluated by its contribution to learner autonomy through measuring language learning strategies in general and metacognitive language learning strategies in particular. The review of literature showed that there were a few studies in the area of Moodle-based education programs and to the best of research knowledge there were no research on Moodle-based language learning/teaching activities. The objective of the current study is, therefore, to evaluate a Moodle-based distance language program through measuring language learning strategies. Then, it will be examined whether there is any relationship between Moodle-based language learning strategies and language learning achievements. To put it more simply, the study is to answer the following questions:

(1) To what extent does Moodle-based language learning program help learners to be autonomous?

(2) Is there any relationship between distance language learning strategies and language learning achievements?

\section{Method}

\subsection{Subjects}

Among the university students as the target population, a nonprobability sample applied (Best \& kahn, 2006) and 100 undergraduate students of Information and Technology (IT) were selected as a convenient sample. Then, 60 participants, 39 males and 21 females, volunteered to participate in the study and filled the questionnaire out. Of these, 6 persons were interviewed to share how this technology-based context could improve their independency from the teacher and class. The sample, therefore, was a large one (Best \& kahn, 2006). All the participants were Farsi native speakers, 19 to 23 years of age. They had mostly passed the General English Language (GEL) course. As IT students, they were homogenous in terms of computer skills and experiences of e-learning. The teacher of the program actually guided the participants through chat rooms and emails. 


\subsection{Instrumentation}

The Strategy Inventory for Language Learning (SILL), $7^{\text {th }}$ edition was used to assess the frequency of EFL/ESL language learning strategies (Oxford, 1990). According to Oxford (1990, 1995 \& 1996), this questionnaire is a "structured survey" instrument with acceptable reliability and high validity to assess language learning strategies and has been used more than 10000 times by late 1995 (Oxford, 1996). Oxford and Burry-Stock (1995) and Oxford (1996) examined the reliability and validity of SILL in different cultural groups and found them as highly acceptable. According to Oxford (1990), SILL can be administered in the respondents' native language or a foreign or second language with minimum measurement error. SILL assesses 6 sides of the participants' language learning strategies, including memory strategies (part A), cognitive strategies (part B), compensation strategies (part C), metacognitive strategies (Part D), affective strategies (E), and social strategies (part F). Participants read every item and rated a five Likert-scale (5-point scale) choice for each strategy describe.

The study also used a teacher-made achievement test to assess the participants' achievement. The achievement scores, therefore, were used as indicators to language learning and showed whether a participant fails or passes the course. These scores were also indicators to rank participants as high or low achievers. Finally, a semi-structured interview was conducted to evaluate how Moodle as a technology could enhance autonomy in language learning.

Participants took part in English for Academic Purposes (EAP) course managed through online materials. Comprehension texts were extracted from 'Special English for the Students of Computer' book written for students of IT. Participants downloaded different texts and tried to understand them with the facilities (pronunciations and online dictionaries) provided in the Moodle context. Speaking and listening were practiced through webcam assisted activities in the Moodle screen. Writing skill was practiced through synchronous (online activities such as chat rooms) and asynchronous activities.

\subsection{Procedures}

At the beginning of the online course, necessary information was given to the students in a real classroom situation and they were asked to record their learning experiences by filling out 50 items in the questionnaire. They were also given the achievement test as a pretest. Subjects received a user and a password and started online learning. Online activities mostly were asynchronous materials. The participants, therefore, made out their plans in a more self-regulated manner than when they were involved in synchronous materials (White, 2003a). In other words, the course design enabled the participants to plan their ways of learning. Having studied for about 4 months (one week before the end of semester), subjects were called to attend a real classroom situation. Meanwhile, they filled out the questionnaire in a think-aloud manner. They were asked to select any item as soon as they chose them. It is important to point that the questionnaire was given to the students in its original form, i.e., in English. One week later, the teacher-made achievement test was administered to the students. The gained score was considered as the indicator of language success or fail. Based on these scores, the most and the least successful language learners (3-3) were interviewed.

\subsection{Data Analysis}

Results from the questionnaire were analyzed based on the profile that proposed by Oxford (1990). According to Oxford, any item in the questionnaire got an interval scale score from 1 to 5 describing the extent of frequent use of that particular item, that is, the higher a student's response, the more frequently the student uses that particular item. Each part of the questionnaire, therefore, provided a sum. All the sums for the different parts, then, were added up to give the total raw score divided by 50 (the number of items in SILL). This number indicated overall average (SILL mean score) which should be between the range of 1.0 to 5.0. The achievement test was also analyzed through calculating overall mean score of the participants. This mean score and the overall average were then compared through a paired-sample ttest used when the same sample is compared in terms of two different variables. This kind of t-test was used to determine whether the average difference (overall average and mean score) is statistically different from zero (Boyce, 2009). Since the t-test results didn't provide evidences for the significance of the differences, Eta squared formula was used to estimate the effect size of the difference (Dörnyei, 2007; p.217). Finally, the potential interrelation between language success (achievement mean score) and language learning strategies was assessed through Pearson productmoment correlation coefficient, a method for comparing two sets of continuous scales data (Brown, 2005). The data gained through interview was also analyzed according to the content analysis.

\subsection{Results and Discussions}

As seen below (Table 1), the mean score of the SILL or overall average is $2.7(\mathrm{M}=2.7, \mathrm{SD}=.50)$ and achievement mean score is 14.62. According to Oxford (1990), this (i.e. 2.7) is a medium level of strategy use. Whether or not these two means are significant, it is necessary to show their t-test results.

Table 1. Mean scores and SD of the SILL

\begin{tabular}{lccl}
\hline test & Mean & SD & N \\
\hline SILL mean score & 2.7 & .50 & 60 \\
Achievement mean score & 14.62 & 2.57 & 60 \\
\hline
\end{tabular}

Note: SILL (Strategy Inventory for Language Learning), SD (Standard deviation), N (Number) 
Paired samples t-test (Table 2) showed that there was a statistical significant difference between achievements mean score and overall SILL mean score. In other words, the results indicated that there was a significant difference between scores for achievement test $(\mathrm{M}=14.62, \mathrm{SD}=2.57)$ and SILL mean score $(\mathrm{M}=2.7, \mathrm{SD}=50), \mathrm{t}(59)=-36.22, \mathrm{p}<.05$ (Table 4.15). Effect size for this test established at .91 computed by eta squired. It showed that the magnitude of the difference in the means was large.

Table 2. Paired Samples Test

\begin{tabular}{|c|c|c|c|c|c|c|c|c|c|}
\hline & & \multicolumn{5}{|c|}{ Paired Differences } & \multirow[t]{2}{*}{$\mathrm{t}$} & \multirow[t]{2}{*}{ df } & \multirow{2}{*}{$\begin{array}{c}\text { Sig. } \\
(2- \\
\text { tailed } \\
\quad)\end{array}$} \\
\hline & & \multirow[t]{2}{*}{ Mean } & \multirow[t]{2}{*}{ SD } & \multirow[t]{2}{*}{$\begin{array}{l}\text { Std. Error } \\
\text { Mean }\end{array}$} & \multicolumn{2}{|c|}{$\begin{array}{l}95 \% \text { Confidence } \\
\text { Interval of the } \\
\text { Difference }\end{array}$} & & & \\
\hline & & & & & Lower & Upper & & & \\
\hline Pair 1 & $\begin{array}{l}\text { Strategy } \\
\text { Usage - } \\
\text { achievement } \\
\text { score }\end{array}$ & -11.88800 & 2.54236 & .32822 & -12.54476 & -11.23124 & -36.220 & 59 & .000 \\
\hline
\end{tabular}

However, Pearson product-moment correlation (table 3 ) showed that $r=.163(p<.05)$, which was a very low positive correlation and not a meaningful one in applied linguistics research.

Table 3. Correlations between SILL mean score and achievement test mean score

\begin{tabular}{llrr}
\hline & & Strategy Usage & $\begin{array}{c}\text { achievement } \\
\text { score }\end{array}$ \\
\hline Strategy Usage & Pearson Correlation & 1 & .163 \\
& Sig. (2-tailed) & & .214 \\
& $\mathrm{~N}$ & 60 & 60 \\
\hline achievement score & Pearson Correlation & .163 & 1 \\
& Sig. (2-tailed) & .214 & 60 \\
& $\mathrm{~N}$ & 60 & \\
\hline
\end{tabular}

In general, Paired samples t-test showed that the differences between achievement mean score and average of overall strategy usage (SILL mean score) were significant and any variance can be a sign of difference. This difference was also valuable; that is, it was in effect important. So, it can be said that in this study the lower the achievement means score, the lower the use of strategies, and vice versa. While these variances were significant, correlation coefficient showed that there is a very low positive correlation between mean of achievement scores and mean of SILL, that is, it is not possible to say if we score high or low on one, we are likely to score high or low on the other. It is important to say that the lack of interrelationship between strategy use and achievement does not imply that the current technology-based context has no or little influence on achievement, but the implication is that it has probably little influence on learning strategies. This may be a reason for lack of success which needs further research.

Therefore, to answer the research questions, it might be possible to say that the Moodle-based language learners showed no interrelating evidence between their language success and their language learning strategies. It is also important to consider that Moodle as a specific technology-based language context intensifies language learning strategies at the medium level. It means that Moodle is a technology-based rather than learner-based language program and, consequently, is an implausible program for promoting autonomy. The data from interview also indicated the same result. In other words, the most and the least successful language learners both believed that this particular technologybased language learning program had few opportunities for improving their autonomy and, hence, their language success. What the good language learners announced as causes of their being successful was their appealing to other learning sources, mostly got from the internet. Almost all the interviewees believed that this technology-based language learning program needed to be reviewed in terms of the ways it handled the assessment processes.

Student A: since there is a time constraint for exam and each item will disappear from the screen after 90 seconds, I feel distracted and can't focus on the items.

As far as learning strategies are concerned, both groups of interviewees had difficulty in how to use note-taking and remember the words (memory strategies), how to use their findings, apply reading strategies such as skimming, scanning, and summarizing, and practice English on the screen (cognitive strategies), how to apply body language (compensation strategies), how to evaluate their progress (metacognitive strategies), how to manage their feelings such 
as being afraid of assessment or being tense or nervous when working with computer technology (affective strategies), and finally how to ask their online questions (social strategies). In contrast to these problems, the technology-based language learners cited some benefits when learning a new language through this program. For example:

Student B: Reading and pronunciation strategies can be easily managed and I can apply word-for-word pronunciation techniques and strategies.

Student C: I use word-for-word translation easily and I can use the dictionary more and more because there are online dictionaries.

Student D: I can plan my time effectively. Whenever I feel enjoyment, I start studying. I have many reading opportunities and it is possible to set my goals and schedules.

Student E: what I have been interested in was the materials and sources designed for further reading. I, myself, use the audio section including many related stories and news about the main ideas of the text.

It is also important to stress that language learners believe that technology-based language learning can be achieved only in a specific language courses. In other words, language learning in general requires a whole range of technologies, and Moodle or any potential program can only teach little bits of language skills.

Student F: I think it is hard to learn a language through this program, albeit for my special course [ESP] it is interesting.

On the whole, these extracts show that Moodle as a technology in language learning might have various influences on language learners' attitudes toward the use of technology as a constructive tool in language learning. So, in conducting technology-based language learning, learners' beliefs and attitudes including learning strategies can be considered as an important factor.

\section{Conclusion and Implications}

According to the aims of this study, it can be possible to say that although Moodle as a technology might result in language success, there is no evidence to prove that this success has been exclusively related to the implications of the technology. On the other hand, this technology, which has been used to enhance the autonomous language learning, has provided the learners with different challenges which might in turn impede autonomy learning. One, for example, is the low level of strategy use among these kinds of technology-based language learners.

As referred to by Oxford (1990) and White (2003a), among others, one indicator for autonomy, not met in this study, is the level of strategy use among language learners. The interview data emphasizes that in the use of technology in language learning it is of great importance to consider language learning strategies and the way these strategies might be integrated to the program. Although findings of the study could be limited to the current program, it is almost clear that in all technology-based language learning programs, language learning strategies in general and metacognitive strategies in particular should be integrated to the program. It seems, however, that Moodle-based language teaching as a technology imposes some limitations on the language learning strategies.

Therefore, further study of language leaning strategies might be conducted in the area of technology-based language learning strategies in general and other specific technologies in particular. It is also suggested to conduct a study on technology-based language learning strategies to provide the literature with a new instrument or a checklist to evaluate learning strategies since Oxford's instrument has been designed for conventional language learning contexts.

The study concludes that English for academic courses requires technologies for academic purposes. Since EAP distance language learners use more metacognitive LLSs (Sarani, Ghonsooly, \& Najjar, 2012), they require a kind of distance program which can smooth the way of using metacognitive abilities. EAP leaners have their own purposes and look for self-regulated strategies which are not seen among the capabilities of the Moodle-based contexts.

It would be logical to design technologies with specific language teaching/learning purposes, rather than using a technology-based program in all contexts. For example, the findings of the current study imply that learning a language through Moodle-based teaching materials impedes the process of being autonomous language learners, which is a prerequisite for language learning at distance contexts.

In general, the implication here is that current distance language learning program has little relationship with students' achievements and has to be replaced or revised. The study also helps distance language teachers in how they can assess the profile of their learners in terms of using strategies. If the study is put in a wider context, it can be said that distance language teachers have to be trained in the area of distance language teaching and they have to pay more attention to the strategy awareness among their distance learners.

\section{References}

Anohina, A. (2005). Analysis of the terminology used in the field of virtual learning. Educational Technology \& Society, 8(3), 91-102.

Bagheri, M. S. \& Yamini, M. \& Riazi, A. (2009). Motivational and learning strategies of Iranian EFL learners exposed to an E-Learning program. The Journal of Teaching Language Skills (JTLS) of Shiraz University, 1(1), 1-35. Retrieved 16 June 2011, from www.sid.ir/en/VEWSSID/J_pdf/131120090101.pdf

Best, J.W., \& kahn, J.V. (2006). Research in education (10th ed.). US: Pearson Education Inc. 
Boyce, A. (2009). The effectiveness of increasing language learning strategy awareness for students studying English as a second language. Unpublished master's thesis, Auckland University of Technology.

Brown, J.D. (2005). Testing in language programs: a Comprehensive guide to English language assessment. New York: McGraw-Hill Companies, Inc.

Chan, S. H., \& Han, A. L. (2005). What goes on when tertiary students are Engaged in an online academic writing course? GEMA Online Journal of Language Studies; 5(2), 1-14.

Cole, J. (2005). Using Moodle: Teaching with the Popular Open Source Course Management System. US: O'Reilly Media, Inc.

Dörnyei, Z. (2007). Research methods in applied linguistics. New York: Oxford University Press.

Gascoigne, C. (2008). Independent second language reading as an interdependent process. In S. Hurd \& T.Lewis (Eds.), Language learning strategies in independent settings (pp. 67-73). UK: Cromwell Press Ltd.

Hansson, p., \& Wenno, D. (2005). Closing the distance: compensatory strategies in distance language education. In B. Holmberg, M. Shelly \& C.White (Eds.), Distance Education and Languages: Evolution and Change (pp. 278-294). UK. Multilingual Matters Ltd.

Holmberg, B., Shelley, M., \& White, C. (2005). Distance education and languages: evolution and change. UK: Cromwell Press Ltd.

Hurd, S. (2008). Affective factors and strategy use in a distance language context: a pilot study using think-aloud verbal protocols. Texas Papers in Foreign Language Education, 11(1), 133-158.

Hurd, S., Beaven, T. \& Ortega, A. (2001). Developing autonomy in a distance language learning context: issues and dilemmas for course writers. System, 29(3), 341-355.

Melton, J. (2006).The LMS moodle: a usability evaluation. Language Issues: HCI, 1, 2-24.

Murphy, L. (2008). Learning logs and strategy development for distance and other independent language learners. In S. Hurd \& T.Lewis (Eds.), Language learning strategies in independent settings (pp. 199-217). UK: Cromwell Press Ltd.

Najjar, R. (2011). Exploring learning strategies used by Iranian ESP distance language learners. Unpublished master's thesis, Sistan \& Baluchestan University, Zahedan, Iran.

Oxford, R. (1990). Language learning strategies: What every teacher should know. Boston, MA: Heinle \& Heinle.

Oxford, R. L., \& Burry-Stock, J. A. (1995). Assessing the use of language learning strategies worldwide with the ESL/EFL version of the strategy inventory for language learning. System, 23(1), 1-23.

Oxford, R. (1996). Employing a questionnaire to assess the use of language learning strategies. Applied Language Learning, 7(1 \& 2), 25-45.

Oxford, R. (2008). Hero with a thousand faces: learner autonomy, learning strategies and learning tactics in independent language learning. In S. Hurd \& T. Lewis (Eds.), Language Learning Strategies in Independent Settings (pp. 41-65). UK: Cromwell Press Ltd.

Ping, W. (2004). Language learning strategies of distance learners. Distance Education in China. Retrieved 20 June 2001, from http://en.cnki.com.cn/Article en/CJFDTOTAL JFJJ200601019.htm

Sarani, A., Ghonsooly, B., \& Najjar, R. (2012). Language learning strategies of EAP distance language learners: a study of Moodle-based distance language learning context. Germany: Lambert Academic Publishing.

Sarani, A., Ghonsooly, B., \& Najjar, R. (2013). Distance context and language learning strategies: a study of Moodlebased context among EFL learners in Iran. Interdisciplinary Journal of Linguistics, 6, 139-156.

White, C. (1995). Autonomy and strategy use in distance foreign language learning: Research findings. System, 23(2), 207-221.

White, C. (2003a). Language Learning in Distance Education.US: Cambridge University Press.

White, C. (2003b). Independent language learning in distance education: current issues. Paper presented at the Independent learning conference, University of Melbourne, Melbourne, Australia. Retrieved 12 June 2011, from http://citeseerx.ist.psu.edu/viewdoc/download?doi=10.1.1.124.4139 \& re.

White, C. (2007). Innovation and identity in distance language learning and teaching. Innovation in Language Learning and Teaching, 1(1), 97-110.

Zahedi, K., \& Dorrimanesh, P. (2008). Metacognitive learning strategies and academic success of TEFL M.A. students in distance education. International Journal of Criminology and Sociological Theory, 1(2), 161-176. 